\title{
Hydrologic Conditions in Kansas, Water Year 2018
}

The U.S. Geological Survey (USGS), in cooperation with Federal, State, and local agencies, maintains a long-term network of hydrologic monitoring stations in Kansas. In water year (WY) 2018, this network included 219 real-time streamgages (hereafter referred to as "gages"). A WY is the 12-month period from October 1 through September 30 and is designated by the calendar year in which it ends. Real-time data are calibrated and validated by USGS personnel throughout the year with regular measurements of streamflow, gage height, and lake levels. These data and accompanying analyses provide an overview of hydrologic conditions in Kansas and help advance the
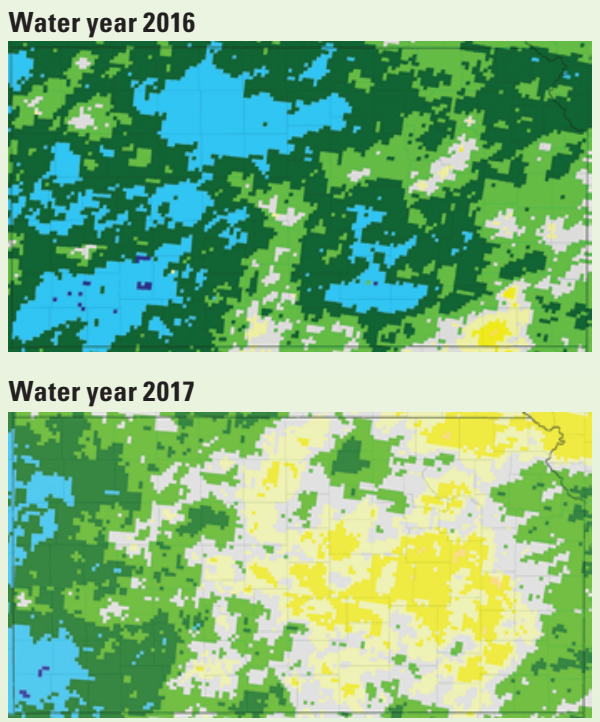

EXPLANATION

Normal precipitation, in percent

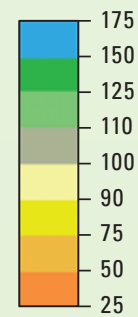

Figure 1. Comparison of statewide percentage of normal (1981-2010) precipitation for water years 2016-17 (https://water.weather.gov/ahps/). understanding of water resources in the State. Annual assessments of hydrological conditions are made by comparing statistical analyses of current and past WY data for the period of record. Longterm monitoring of hydrologic conditions in Kansas provides imperative information for protecting human life and property, managing water supplies, forecasting floods, operating reservoirs, designing bridges and culverts, processing interstate and intrastate water rights claims, forecasting ecological conditions, and many other uses.

\section{Preceding Conditions/ Precipitation Overview/Drought Conditions}

WY 2016 had above average precipitation in Kansas, whereas WY 2017 had normal to above normal precipitation in the western third and eastern border of the State and slightly below normal precipitation in much of the central and eastern parts of the State (fig. 1) (National Oceanic and Atmospheric Administration, 2018). During WY 2018, normal to slightly above normal precipitation trends continued in the western part of the State, stretching into north-central Kansas. South-central and eastern Kansas experienced below normal precipitation. The percentage of normal precipitation in WY 18 is shown in figure 2.

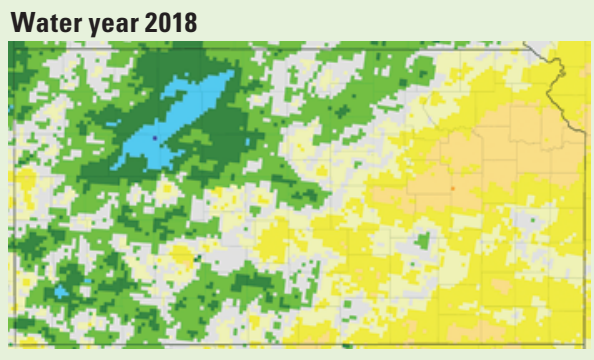

Figure 2. Comparison of statewide percentage of normal (1981-2010) precipitation for water year 2018 (https:// water.weather.gov/ahps/).
At the beginning of WY 2018 , about 40 percent of the State was classified as abnormally dry, 10 percent as moderate drought, and about 1 percent as severe drought, primarily throughout central Kansas and the northeast corner of the State (National Drought Mitigation Center, 2018). By the end of WY 2018, drought conditions transitioned from the central part of Kansas to northeast and east-central Kansas, which had drought intensity classifications of about 21 percent as abnormally dry, nearly 15 percent as moderate drought, 10 percent as severe drought, about 6 percent as extreme drought, and about 1 percent as exceptional drought (National Drought Mitigation Center, 2018), as shown in figures 3 and $4 A$.

Areas of drought in Kansas at the end of WY 2018 correspond to areas of below

Beginning of water year 2018

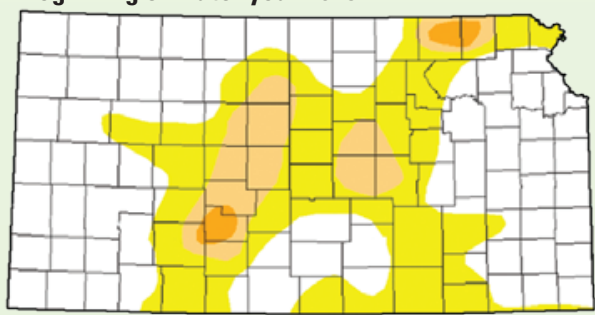

End of water year 2018
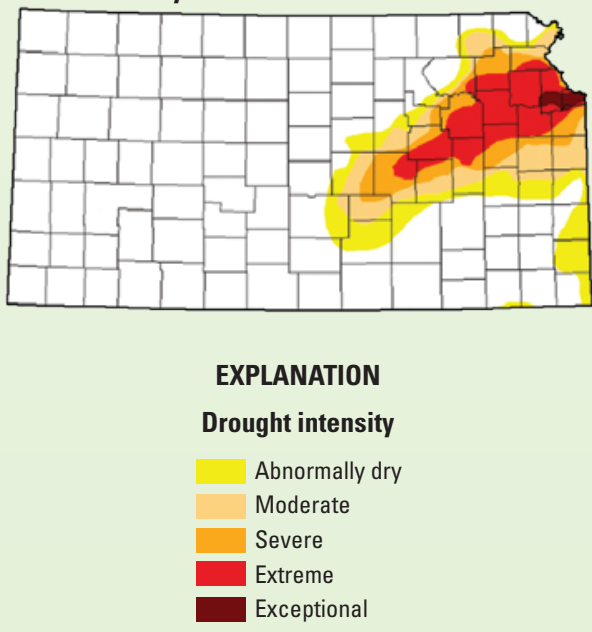

Figure 3. Comparison of drought conditions in Kansas at the beginning and end of water year 2018 (https:// droughtmonitor.unl.edu/). 


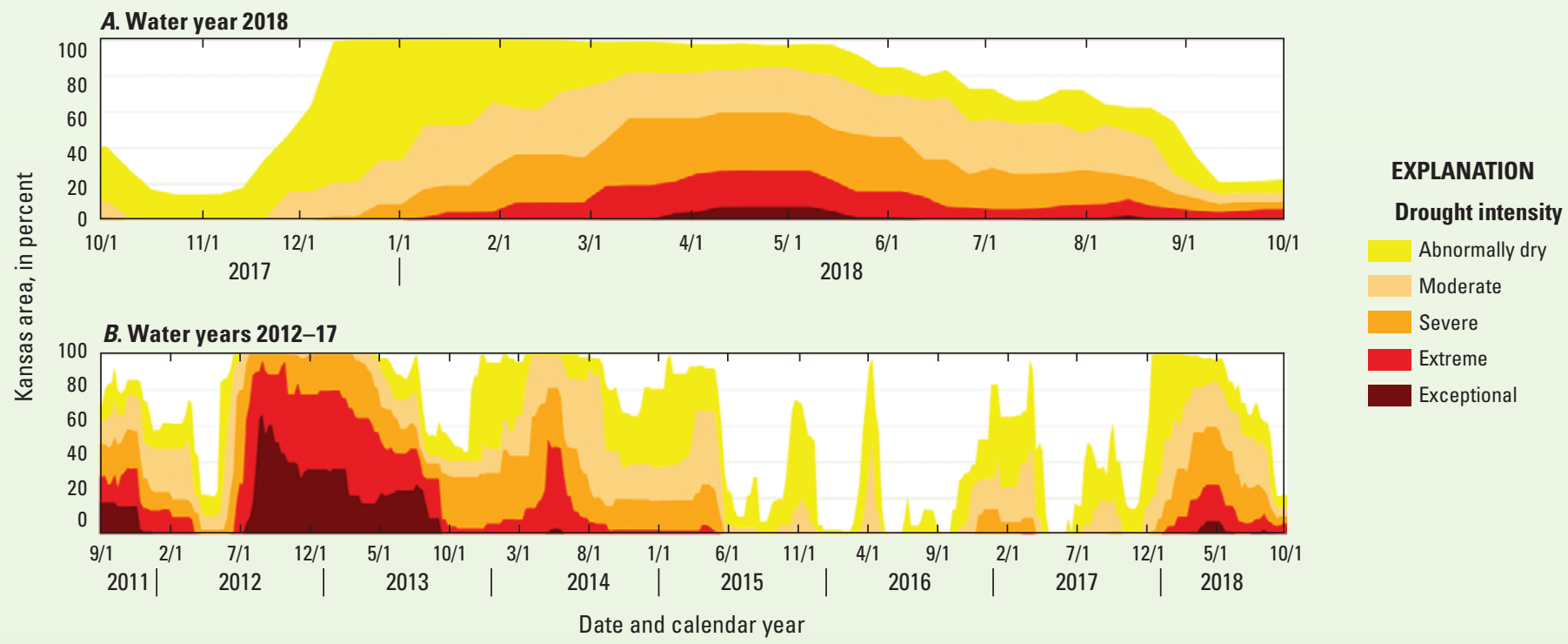

Figure 4. Percentage of areal coverage of drought conditions. $A$, Drought conditions for water year 2018; $B$, Drought conditions for water years 2012-17, Kansas (https://droughtmonitor.unl.edu/).

average precipitation throughout the State during WY 2018. In comparison to previous WYs (fig. 4B), WY 2018 had a greater percentage of areal coverage of drought conditions than WYs 2015-17, and periods of exceptional drought conditions. However, the percentage of areal coverage of drought conditions did not reach the same magnitudes observed in WYs 2012 and 2013 (National Drought Mitigation Center, 2018).

\section{Streamflow Conditions and Drainage Basin Runoff}

Kansas experienced a wide range of streamflow conditions throughout WY 2018. At the beginning of WY 2018, most of the State experienced normal (25th-75th percentile) streamflow conditions, but above normal (76th-90th percentile) and much above normal (greater than 90th percentile) conditions were observed in the western, northeastern, and southeastern parts of the State. Below normal (10th-24th percentile) conditions were observed in central Kansas and the southwest corner of the State. The extent of much below normal and below normal streamflow conditions increased in coverage during the first half of WY 2018. By April, most of the eastern and southern parts of Kansas experienced below normal and much below normal conditions (fig. 5) that corresponds to drought condition locations (fig. 3), although some western Kansas streamflow conditions remained normal. In July, stream conditions in the western part of the State ranged between normal and much above normal, whereas below normal and much below normal conditions continued in parts of eastern and southwest Kansas. By the
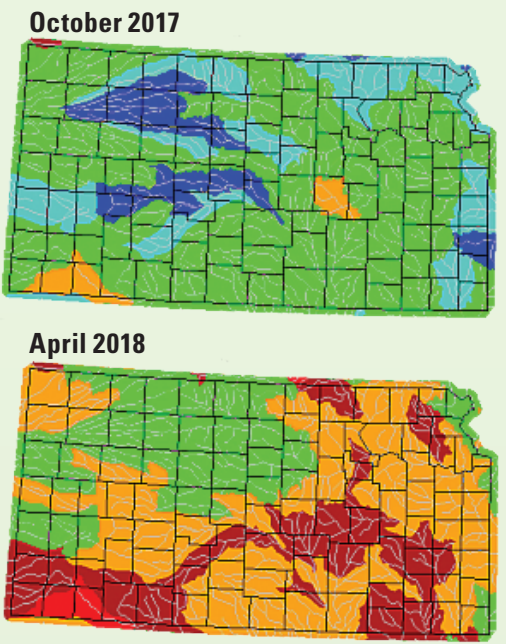

July 2018

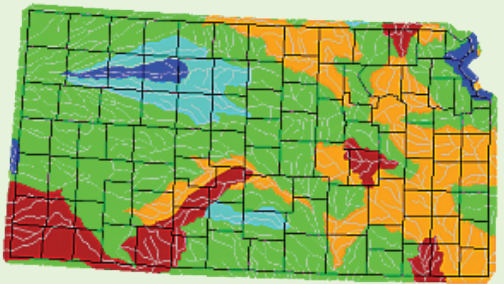

end of WY 2018, most stream conditions in Kansas fell within the normal, above normal, and much above normal conditions, but a small area in the southwest corner of the State had below normal conditions (fig. 5).
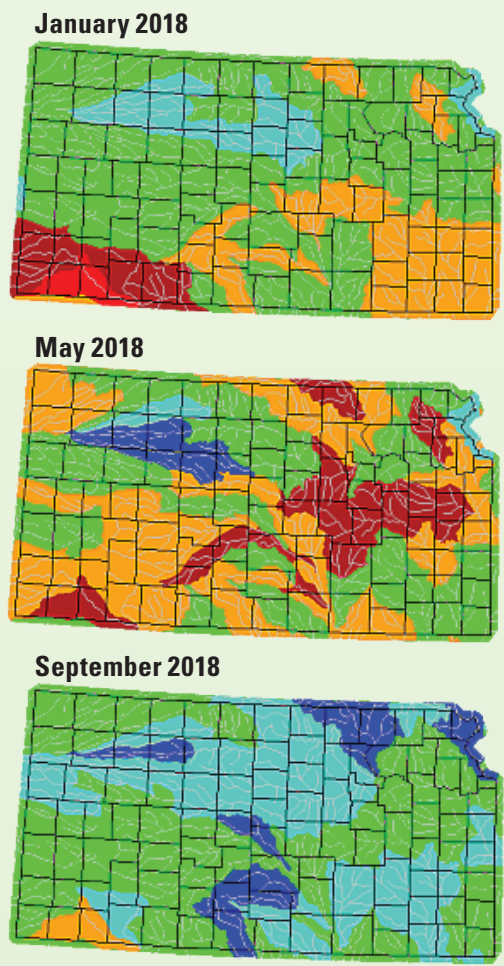

\section{EXPLANATION}

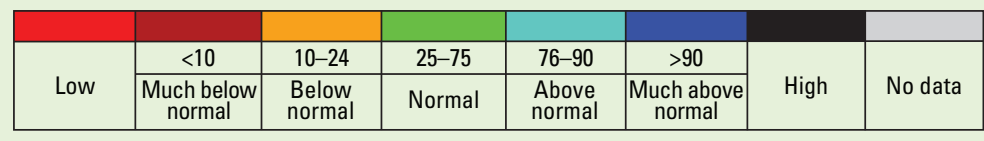

Percentile classes

Figure 5. Comparison of monthly streamflow conditions across Kansas throughout water year 2018 (https://waterwatch.usgs.gov/). 


\section{Cumulative Streamflow at Selected Streamgages}

Two gages were selected to represent streamflow conditions for the State during WY 2018. One gage was selected in the western part of the State, where precipitation and subsequent streamflow conditions were higher during WY 2018, and one gage was selected in eastern Kansas, where emerging drought conditions were present during most of the WY. The locations of these gages are shown in figure 6 .

The Smoky Hill River near Arnold, Kansas (USGS station 06861000), gage (shown in figs. 7 and 8 during low and higher flows, respectively) represents western Kansas, in particular the Smoky Hill-Saline watershed, which received above normal precipitation during WY 2018. The Smoky Hill River originates in eastern Colorado and flows east into the Kansas River near Junction City, Kans. (not shown), and it has a drainage area of 5,220 square miles $\left(\mathrm{mi}^{2}\right.$, U.S. Geological Survey, 2018). At the beginning of the WY, observed cumulative streamflow (fig. 9) was above the 75th percentile of the daily mean cumulative streamflow. A dry winter that resulted in a trajectory below the 50th percentile (cumulative streamflow of daily median) followed. Heavy precipitation events in May, followed by persistent rainfall throughout the summer, resulted in the observed cumulative streamflow rising above the 75th percentile. Although observed cumulative streamflow rose above the 75 th percentile, it was still more than an order of magnitude below the highest observed cumulative streamflow for the 67-year history of the gage, in part, because of antecedent drought conditions.

Observed cumulative streamflow at the Dragoon Creek near Burlingame, Kans. (USGS station 06911900), gage (shown in figs. 10 and 11 during zero-low and higher flows, respectively) represents drought conditions that intensified during WY 2018 in eastern Kansas (fig. 12). Dragoon Creek, with a drainage area of $114 \mathrm{mi}^{2}$, originates in northeastern Kansas (U.S. Geological Survey, 2018). Observed cumulative streamflow at the beginning of the WY was near the 50th percentile of daily mean cumulative streamflow, followed by a progression toward and then below the cumulative daily 25 th percentile. The WY ended slightly above the cumulative daily 25 th percentile after

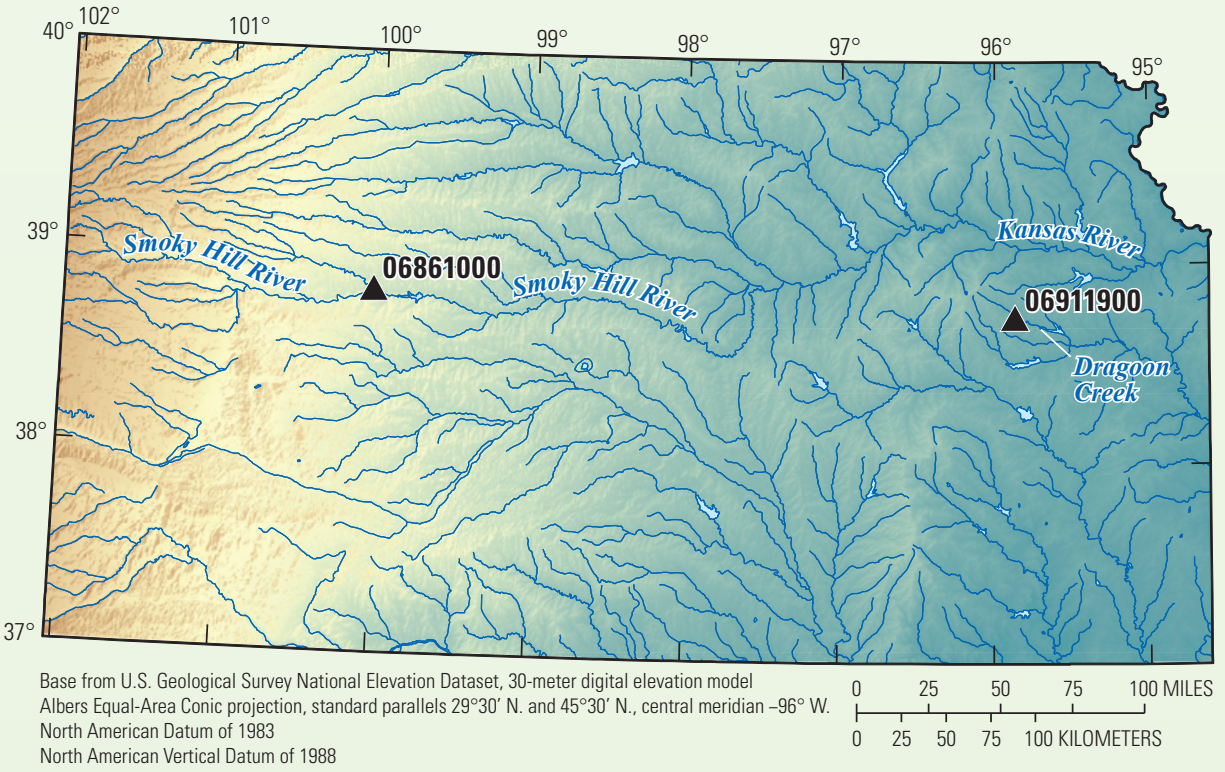

EXPLANATION

Elevation, in feet above
North American
Vertical Datum
of $\mathbf{1 9 8 8}$
$-4,039$
-
-679

06911900 U.S. Geological Survey continuous-record streamgage and site identifier Reservoir

Figure 6. Locations of selected U.S. Geological Survey streamgages.
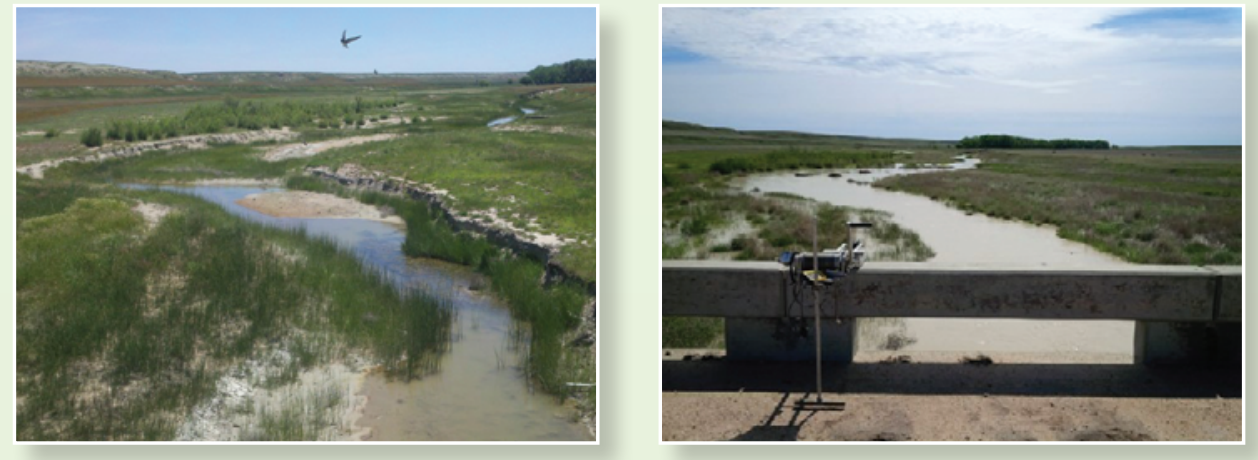

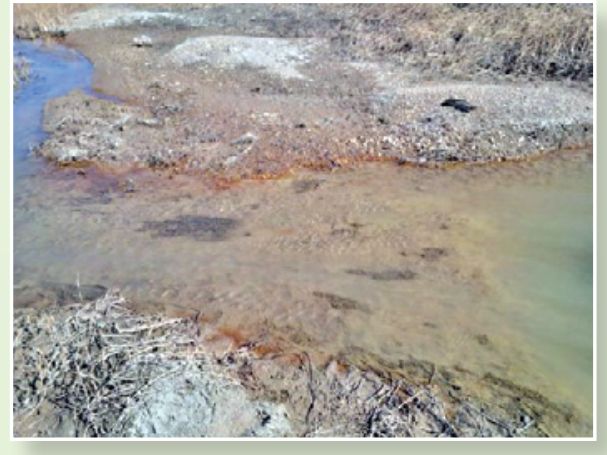

Figure 7. Smoky Hill River near Arnold, Kansas, during low flow conditions.

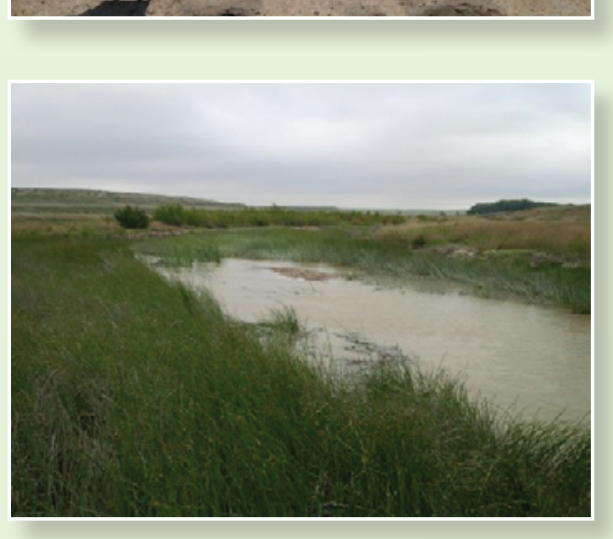

Figure 8. Smoky Hill River near Arnold, Kansas, during higher flow conditions. 


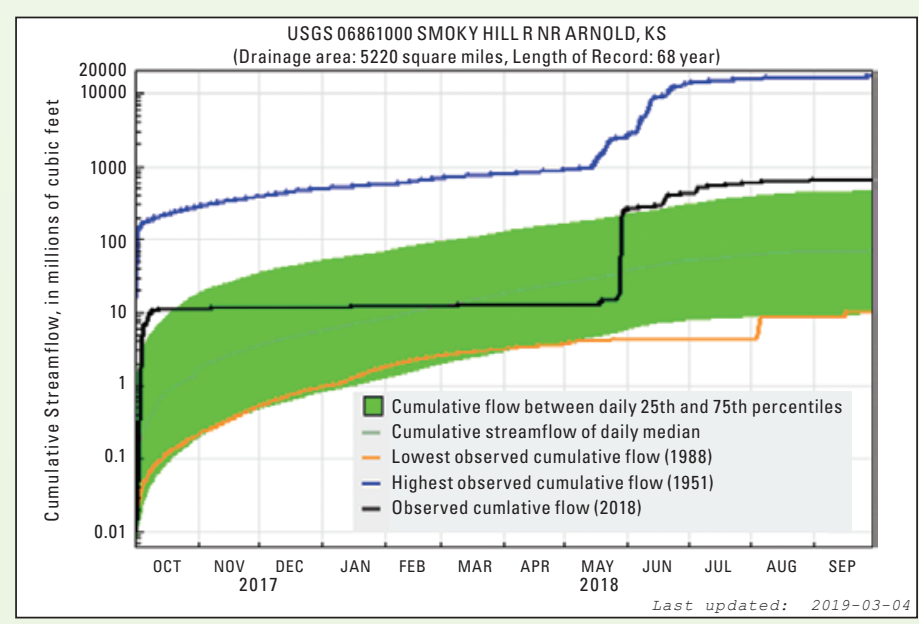

Figure 9. Observed cumulative streamflow compared to cumulative streamflow of daily mean for the Smoky Hill River near Arnold, Kansas (U.S. Geological Survey station 06861000), streamgage during water year 2018 (https://waterwatch. usgs.gov/).
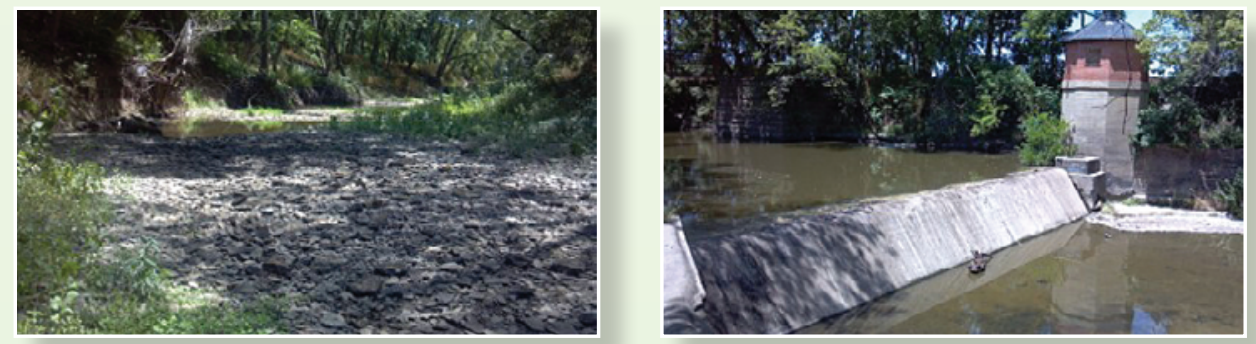

Figure 10. Dragoon Creek near Burlingame, Kansas, during zero-low flow conditions.
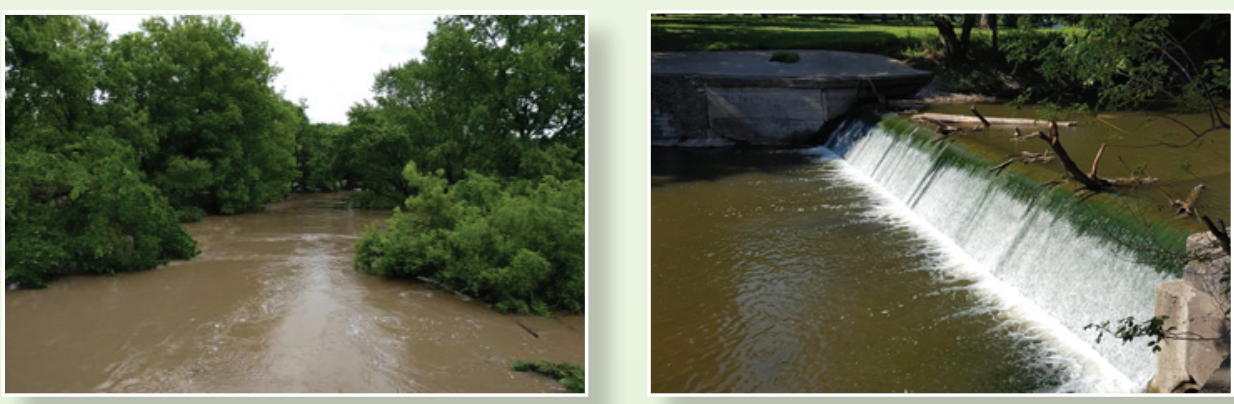

Figure 11. Dragoon Creek near Burlingame, Kansas, during higher flow conditions.

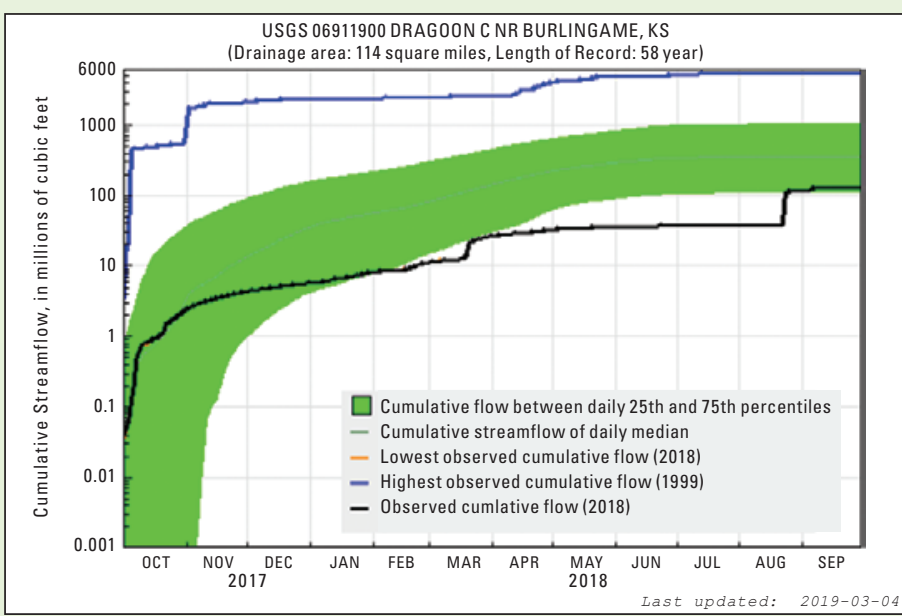

Figure 12. Observed cumulative streamflow compared to cumulative streamflow of daily mean for the Dragoon Creek near Burlingame, Kansas (U.S. Geological Survey station 06911900), streamgage during water year 2018 (https://waterwatch. usgs.gov/). heavy precipitation events in August; however, WY 2018 had the lowest observed cumulative streamflow for the 58-year period of record for this gage.

\section{Summary}

Streamflow conditions in Kansas during WY 2018 reflected precipitation and drought trends in the State. Above normal precipitation in western Kansas corresponds to the lessening of preexisting drought conditions. In the east, below normal precipitation corresponds to worsening drought conditions. The WY ended with predominately above normal and much above normal streamflow across the State.

\section{References Cited}

National Drought Mitigation Center, 2018, United States Drought Monitor-Kansas: National Drought Mitigation Center, U.S. Drought Monitor web page, accessed November 7 , 2018, at https://droughtmonitor.unl. edu/.

National Oceanic and Atmospheric Administration, 2018, Advanced hydrologic prediction service-2018 precipitation maps for Kansas: National Oceanic and Atmospheric Administration, National Weather Service web page, accessed November 7, 2018, at https://water.weather.gov/ precip/.

U.S. Geological Survey, 2018, USGS water data for the nation: U.S. Geological Survey National Water Information System database, accessed November 7, 2018, at https://doi. org/10.5066/F7P55KJN.

For more information about this publication, contact:

Director, USGS Kansas Water Science Center

1217 Biltmore Drive

Lawrence, KS 66049

785-842-9909

For additional information, visit: https:// www.usgs.gov/centers/kswsc

Publishing support provided by the Rolla Publishing Service Center 